\title{
CRITICAL FRAMING: HOW INDONESIAN EFL STUDENTS CRITICIZE TEXTS AND RECONSTRUCT GENDER EQUALITY IN EFL READING CLASS
}

\author{
Intan Nuvitasari ${ }^{1}$ \\ Universitas Negeri Surabaya \\ Pratiwi Retnaningdyah ${ }^{2}$ \\ Universitas Negeri Surabaya \\ Ahmad Munir ${ }^{3}$ \\ Universitas Negeri Surabaya \\ intannuvitasari@gmail.com ${ }^{1}$ \\ Submit, 02-05-2020 Accepted, 23-06-2020 Publish, 24-06-2020
}

\begin{abstract}
This study was proposed to reveal how students criticize text and reconstruct gender equality through critical framing provided by the teacher. To conduct the research, field notes, recording on audio and video, and also students' artifact (the result of discussion) were used. The text used in this research was the synopsis of Mustang (2015). The data was analyzed using critical discourse by looking at the influence of the linguistic used by the teacher and the text. The result showed that in criticizing text, female and male group is influenced by the linguistic used by the teacher and text and the power of the text and teacher can empower student to reconstruct gender equality and reject gender inequality, while male's group was only influenced by the teacher. In addition, the linguistic used by the teacher also may lead them to relate with their society. In conclusion, female and males students are influenced by linguistic used in criticizing text.
\end{abstract}

Keywords: Critical Framing, Gender Equality, Gender Inequality.

\section{INTRODUCTION}

Indonesian still face social issue because of the diversity of its cultures. One of social issues that still become problem in Indonesia is gender inequality. In 2017 the UN Development Program, Indonesia ranked 104 out of 160 nations in a gender inequality index assessing gender inequality in education, reproductive health as well as economic and political engagement. In recent years this rank has little changed and it is lower than most Asian neighbors (Diprose, 2019). Addressing maternal mortals remains a major challenge, especially as accessible birth facilities in the many smaller islands throughout the archipelago are difficult to provide properly qualified medical personnel (Diprose, 2019). In rural area, 
someone's knowledge regarding with gender equality is still low. Thus, gender inequality still happen there and many university students come from rural area, even though they have knowledge regarding with gender equality, but they do not have voice to against gender inequality since they must obey every culture in their area (Fauziah, et.al, 2015). Thus, it is essential for educator to provide an activity that leads the students to share their voice regarding with this issue.

Education played the importance part to the advancement of education and culture. There are a few definitions of literacy within the past and in cutting edge time. Within the past most of individuals characterize Literacy was the capacity to type in and read and the individuals who experienced literacy is called as literate person. According to UNESCO in 1962, literate individual could be a individual who have capacity to type in and read and the individual may know how to socialize at homes that the individual lives in. Within the cutting edge zone literacy includes a wide meaning, more than just reading and composing. Literacy may be a perusing capacity which lead an individual to be able to comprehend and decipher meaning in a few sorts of content and it will be utilized to deliberate life, such as: socializing that relate to the educational accomplishment (Kulju et al., 2018).

In education point of view, literacy gets to be not only a tool for learners in understanding and applying their knowledge that they get from school but moreover the behavior of students associating and having a great relationship with their environment exterior the school. According to the World Economic Forum (2016) students need Sixteen Literacy skills in order to survive in twentieth century namely Read and Write, Mathematics, Science, Technology and Communication, Finance, Culture and Nationality, Critical Thinking, Creative Thinking, Communication, Collaboration, curiosity, Initiative, Persistence, Adaptation, Leadership, and Socio-Cultural Skill (Laksono \& Retnaningdyah, 2018). It means that students should be able to read and understand not only Print text but also surrounding condition and environment which usually called as Multiliteracy. Multliteracy is a skill to deliver and understand the ideas with diverse ways such as conventional text, Innovative Text, Symbol, and multimedia (Multimodal text) (Boche \& Benjamin, 2014).

The new London Group utilized multiliteracies to refer to literacy pedagogy which react to global societies and diversity in society and the blossoming literary structures managed by multimodal resources (Cope \& Kalantzis, 2015). Multimodality is used in multiliteracies since multimodality is as the idea of communication that subsumes the written, the visual, the gestural and the material into one substance of multimodal text (Pahl \& Rowsell, 2005). Multimodal text presents some modes of text which consist of storybooks, fables, pop-up, advertisements, poetry, songs, artwork, and so on as the way to 
communicate and to make meaning (Pahl \& Rowsel, 2005). To facilitate students to think critically, multiliteracies provide critical framing.

Critical framing could be a framework on multiliteracies pedagogy that lead learners to think critically, to relate their learning into social settings, to assist learners in developing their learning (Cope \& Kalantzis, 2015). Critical framing is not only giving critical thinking skills, but it is additionally giving the capacity to understand and mindful with their society (Cope \& Kalantzis, 2015). Thus, this study will be related in social context and that is gender inequality and gender equality.

Mustang (2015) is the Turkish-French movie. For her feature film debut 2015 the Turkish-French film director Deniz Gaze Erguven made an in international co-production of Mustang. The film shows five young orphaned sisters and their problems as children in a conservative society, situated in a remote Turkish village. The incident that causes the family to respond against the five sisters. Then, some cases regarding with gender inequality happened there (Grierson, 2015). Thus, the synopsis will be used by the teacher to practice critical framing. Rogers \& Mosley, (2008); Ajayi, (2015); Mills, (2006) had done research about social issue used in applying critical framing in pedagogical term. Students have shown that their lives and their societies can have a meaning, and they can shift their perspective on the issue within their society. Indonesia students also have their own cultural background that may influence them in criticizing text. Thus, this research will search the way students criticize texts and reject gender inequality by critical framing provided by the teacher. This process was used critical discourse analysis as a base of critical framing.

\section{LITERATURE REVIEW}

\section{Critical Framing}

Critical framing alludes to the understanding of person sense definitions within the social and cultural setting. It guarantees the learners step back and see it dispassionately in connection to their background (Cope \& Kalantzis, 2015). Critical framing makes sense of overt instruction and situated practice through characterizing social implications and meaning-building goals (Cope \& Kalantzis, 2015). All through Multiliteracies pedagogy,' critical' incorporates the review of writings and the examining of the desires of individuals within the exchange stage. The aim of Critical Framing is to permit the student to create his or her through authority and impact and comprehension of specific information structures and social practice in terms of the geographical, cultural, social, financial, ideological and social connections. In this way, it is crucial for teacher to help students through denaturalizing what they have mastered (Cope \& Kalantzis, 2015). 
Through this segment of pedagogy, teachers have to assist students in denaturizing what the learners have studied and acquired. It has some goals; students can get the personal and intellectual room they have learned; critique this constructively; take its contextual role into account; use it and expand it creatively; ultimately evolve within old and new cultures (Cope \& Kalantzis, 2015).

\section{Critical Discourse Analysis and Literacy}

The basic theoretical framework used in this study of Critical Discourse Analysis was by Gee. The focus of critical discourse analysis is the produce and the reproduce domination of language and abuse of power and it leads to injustice and inequality (Gungor \& Prins, 2010). The concept of discourse, literacy and identity by Gee refers to language and cultural models. These model relate to way to combine and to integrate interactions, actions and language and relate to way to think, to value, to believe and to use some symbols, objects and tools to enact a particular socially recognizable identity. Critical discourse and critical framing are relate since critical framing used critical discourse to frame the students by using teacher's power (Wallace, 2003).

The basic theoretical framework by Fairclough is also used to against gender inequality. CDA relates to language, power and ideology. The origination of power as a deviated circulation of power over the creation, dissemination, and utilization of writings in explicit settings is vital to this line of thought. Power is, in this unique circumstance, clearly ideological and verbose, and each demonstration of etymological cooperation, because of existing social imbalances, turns out to be conceivably ideological. A significant objective of CDA is along these lines to build up a structure of examination that can turn into "an asset for individuals who are battling against control and persecution in its semantic structures"(Rogers, 2011).

\section{A Reject to Gender Inequality and Propelling Gender Equality}

Inequalities faced by young ladies can start directly during childbirth and follow them for their entire lives. In certain nations, young ladies are denied of access to medicinal services or appropriate nourishment, prompting a higher death rate. As young ladies move into puberty, sexual orientation differences augment. Youngster marriage influences young ladies definitely more than young men. Universally, almost 15 million young ladies under age 18 are hitched each year or 37,000 every day. Young marriage influences young ladies' education. Around $33 \%$ of developing nations have not accomplished sexual orientation equality in essential instruction. In sub-Saharan Africa, Oceania and Western Asia, young ladies still face boundaries in entering both primary and secondary school. 
Impediments in training convert into absence of access to aptitudes and constrained open doors in the work advertise.

Ladies' and young ladies' empowerment is important to extend financial development and advance social improvement. The full cooperation of ladies in labor powers would add rate focuses to most national development rates - twofold digits as a rule. Truly. Around the world, 35 percent of ladies between 15-49 years old have encountered physical and additionally sexual private accomplice savagery or non-accomplice sexual brutality. 1 out of 3 young ladies matured 1519 have encountered some type of female genital mutilation/cutting in the 29 nations in Africa and the Middle East, where the unsafe practice is generally regular with a high danger of delayed dying, disease (including HIV), labor inconveniences, barrenness and death.

Gender equality is an essential human right. Propelling sexual orientation equity is basic to all territories of a sound society, from diminishing destitution to advancing the well-being, training, insurance and the prosperity of young ladies and young men.

1. If you are a young lady, you can remain in school, help engage your female cohorts to do likewise and battle for your entitlement to get to sexual and conceptive wellbeing administrations.

2. If you are a woman, you can address unconscious inclinations and implicit asso ciations which are a barrier to equal opportunities unintentionally and often inv isibly.

3. If you're a man or a boy, you should work with women and girls to promote eq uality between men and women and to have safe, respectful ties.

4. Training can be funded to curtail cultural practices such as female genital mutil ation and to amend discriminatory legislation, restricting women's rights and st opping them from realizing their full potential (United Nation, 2014).

\section{RESEARCH METHOD}

\section{Research Design}

The researcher collected the data through video recording, field notes and student's artefact. The call was set by small group discussion and seminar discussion. Small group discussion was done to discuss the text with their group members and seminar discussion was done to present the result of their small group discussion.

In setting class, the teacher provides a synopsis of movie that is about gender inequality, entitled "Mustang". Mustang was a Turkish-French movie which was released in 2015 . The teacher set the class by using critical framing model as following

1. The teacher asked the students to analyze the texts. 
2. The teacher asked the students to work together in group based on male and female, so there were two groups. They should work under these three questions: a) do you see any gender inequality in the story?, b) can you mention what gender inequality happen there and relate to your society?, c) what should people do to make gender equality?

3. The teacher asked the students to share their ideas in big group.

\section{Participant}

The subject of the study is a teacher and students in one of universities in Surabaya, Indonesia. The teacher has background knowledge regarding with multiliteracies, critical literacy and critical discourse analysis and the teacher has applied critical framing in some classes. The students were between 20-21 years old.

\section{Data Collection}

The data was collected in field notes, recording on audio and video, and also students' artifact (the result of discussion). It needed two weeks. First week was used to discuss about the content of the Mustang's synopsis and the second week was used to analyze and to discuss the result of their analyzing. Video recording and field notes were used during class and the student's artifact were used to see their result of analyzing in written.

\section{Analysis}

The analysis used in this research was critical discourse analysis. In education, critical discourse analysis is used to explore the relationship between the language used in text and talk function (By, Fairclough, \& Longman, 1997). In this study, critical discourse analysis is used to explore the relationship between the linguistic used in texts in Mustang and the critical framing model used by the teacher to reconstruct the students' gender equality ideology. Then the result will be described and interpreted as theory by Fairclough.

\section{FINDINGS}

\section{Indonesian Student Critique Texts}

The first comment was by female's group that is presented in the following:

"There is gender inequality there. It can be seen how the sisters are pushed to be arranged marriage with men that they do not know. Women are became an object of a mistake because of they went go somewhere with men. They also had to follow some rules, such as: they cannot go out from home for a long time. This is as gender inequality case. Compare to Indonesia, this is also happen in rural area, how woman should marry 
with man that they do not love because their parents introduced them to a man that their parents like. In fact, many cases that woman should not have any relationship with man that their parents do not like. Thus, there are also some cases that woman left their home to marry with their man, but there are also some cases that the woman accept their future husband from their parents since they do not have any option. In Indonesia, there is also case that girl cannot go out from home until 9 p.m. if they go home 9 p.m. above, their parents will be angry to them and their neighbors also will talk about that with others like that is the bad thing. This story taught a woman to reject injustice that happen to our life. Look at their way to reject the arranged marriage. They help each other. They think how to get way to avoid coercion. That's the woman should do"

In criticizing the text, female's positioned them (as woman) in the text and it leads them to argue with their position. It can be seen that they reject injustice that happen to woman by arguing "This story taught a woman to reject injustice that happen to our life. Look at their way to reject the arranged marriage”. Female's group also bring Indonesian case that happen to woman, such as: arranged marriage, time to go home for woman, if they go outside their house. For female's group, those cases are gender inequality cases as the story has. Then, the linguistic used within the text in synopsis of Mustang (2015) lead the woman showed their rejection to the gender inequality since the story provided the way the sister tried to avoid arranged marriage. It can be seen by some sentences in their comment "This story taught a woman to reject injustice that happen to our life. Look at their way to reject the arranged marriage. They help each other. They think how to get way to avoid paksaan. That's the woman should do". It shows how the discourse empower the female's group to reject gender inequality.

The second comment was by male's group that is presented in the following:

"Gender inequality was happened in this story, when girls should marry by the request of their grandmother. In addition, they do not know with the boys. This case also happened in Indonesia. Thus, many stories in Indonesia showed relationship was broken up since the girls are asked to marry with boys that are the option of their parents, even though the relationship was established for several years. There is also gender inequality in the movie, when the sisters' uncle were angry with them since one of them went home with boy, but one day three of them became sexual harassment victim by their uncle. This is so cruel and unforgivable. Many cases also happened in Indonesia, like the woman does not have voice. In fact, the case can be happened for several years and the woman keep silent since they were threatened by the doer." 
The male's group comment also showed how gender inequality happened to woman and they relate to an example that happened near them. Their comment is mostly influenced by their teacher's question that leads them to share their ideas regarding with gender inequality. It also shows that how teachers linguistic used empower their students to share their opinion regarding with an issue. In contrast, male's group was mostly empowered by their teacher's question to share their ideas. Female's group can share their ideas by empower of the discourse by sharing how the sisters in the story tried to reject injustice that happened to them while male's group they are empower by the discourse since there is linguistic used by the teacher in framing the students by providing some questions while analyzing. The student's comment on other group ideas is presented as the following:

Male's group: "girls should go home earlier since it was not good for them since many crimes that can be happened while on the street. Therefore, parents did not allow girls to go home at late night."

Female's group: "girls also have something to do. They may be working or having organization at university. Thus, there should be government role to make everyone safe. Women also have right to advance themselves."

This reaction by Male's group showed how their linguistic used is influenced by their social identity since they stated based on the reality that happened in the society.

\section{Indonesian Students Reject Gender Inequality and Reconstruct Gender Equality}

Before asking students to answer these questions, the teacher commented to the discussion result by stating that the students have commented that gender inequality still happened, including in Indonesia. Even though in big cities in Indonesia, gender inequality has been decreased, but we cannot deny that rural area still happened the issue because they have low education about gender inequality. Now, it is your turn to promote gender equality and the teacher asked each group to share their ideas to make gender equality.

Female's group ideas to reject gender inequality and reconstruct gender equality is presented as following:

"A rejection to gender inequality must be done by everyone. It cannot be done only by a gender that becomes a victim, so a rejection must be done by both man and woman. They must support each other to deny gender inequality. As woman, we have to help other woman, when they become a victim of gender inequality. We may not blame them since many cases show that how other women blame a woman who become a victim, such as: there is sexual harassment that happen to woman. Other women sometimes blame them by saying that they cannot keep themselves by 
wearing a proper clothes. In fact, the woman is victim, so first thing that we have to do is we help and support each other. Stop blaming the victim of gender inequality case! Like in the story, the sisters wanted to break the barriers that leads them became so difficult to Woman needs to follow some campaign regarding with gender inequality since we need to learn what woman's right is, in order to we may have voice to deliver our right or we may give campaign to woman in rural area about woman's right since gender inequality in Indonesia mostly happen to women in rural area".

In reconstructing gender equality and to make them aware with gender equality, it cannot be denied that the linguistic used by the teacher in critical framing process influences the students. It can be seen both share their ideas regarding with gender equality since the teacher construct them to think what they should do to reject gender inequality. Looking at the way female's group provide way in gender equality, it is influenced by the discourse in the text since the text provide how the sisters help each other and they relate to Indonesia that still low to help each other.

"Men must help women to achieve gender equality, we have to respect them. When gender inequality happen to woman and we know it we help to them to overcome their gender inequality. We may not see woman as a weak person that needs help, but we should view them as human like us that we should help each other as human".

Different with female's idea, male's group idea is more directly to the point. It can be seen that they directly argued how to avoid gender inequality. They directly stated "Men must help women to....."

\section{DISCUSSION}

\section{Indonesian Student Critique Texts}

In criticizing text, linguistic used can empower students. It can be seen how teacher linguistic used empower students to share their opinion regarding with an issue. As stated by Rogers, the linguistic used can influence someone's ideology (Rogers, 2011). Regarding with critical framing, it shows how the teacher's question leads them to understand with their social situation near them (New London Group, 2000). Then, when the female's group stated the same cases that happen to the story and Indonesia, it shows how discourse and literacy provides someone's identity (Wallace, 2003).

In contrast, male's group was mostly empowered by their teacher's question to share their ideas. Female's group can share their ideas by empower of the discourse by sharing how the sisters in the story tried to reject injustice that happened to them while male's group they are empower by the discourse since 
there is linguistic used by the teacher in framing the students by providing some questions while analyzing. In criticizing text, male's group is influenced by linguistic used which shows their social identity since they stated based on the reality that happened in the society. According to Gee, in critical discourse analysis the way people think mostly influenced by the social recognition that shows their identity (Wallace, 2003). While female's group comment showed the teacher's power in providing critical framing and the text's power empower them to still reject gender inequality. As stated by Rogers, power appears because imbalances also appears (Rogers, 2011)

\section{Indonesian Students Reject Gender Inequality and Reconstruct Gender Equality}

In reconstructing gender equality, female's group is influenced by the discourse in the text since the text provide how the sisters help each other and they relate to Indonesia that still low to help each other. It shows by they provide example. It shows that critical framing provided by the teacher leads the students to have ideological regarding with gender equality (Cope \& Kalantzis, 2015) and someone's thinking is influenced by social recognition regarding with the issue (Rogers, 2011). While male's group in reconstructing gender equality was not influenced by the text since in sharing ideas to reject gender inequality, they directly stated by the case in society. Their ideas regarding with gender equality is also as same as united nation that as men, they should help woman to achieve gender equality (united nation, 2014).

\section{CONCLUSION}

This study revealed how students criticize text, reject gender inequality and reconstruct gender equality. by observation data result, it showed that female and male groups criticize gender inequality influenced by linguistic used by the teacher in providing critical framing and the synopsis of Mustang (2015) and the findings also revealed female group is also influenced by linguistic used by the teacher in providing critical framing and the synopsis of Mustang (2015) to reconstruct gender equality while male's group is only influenced by the teacher. Power that is used by the teacher also empowers female group to reject gender inequality. It shows that critical framing and the used of synopsis of Mustang (2015) text influenced someone's thinking. However, this research did not reveal the practice in real life whether it is successfully reconstruct them regarding with gender equality. Thus, it is essential to further researcher to conduct the practice of critical framing that has been applied at class. 


\section{REFERENCES}

Ajayi, L. (2015). Critical Multimodal Literacy: How Nigerian Female Students Critique Texts and Reconstruct Unequal Social Structures. Journal of Literacy Research, 47(2), 216-244. https://doi.org/10.1177/1086296X15618478

Boche, \& Benjamin. (2014). Multiliteracies in the Classroom: Emerging Conceptions of First-year Teachers. Journal of Language and Literacy Education, 10(1), 114-135.

Cope, B., \& Kalantzis, M. (2015). A Pedagogy of Multiliteracies: Learning by Design. New York: Palgrave Macmillan.

Fauziah, R., Mulyana, N., \& Raharjo, S., T. (2015). Pengetahuan Masyarakat Desa tentang Kesetaraan Gender. Prosiding Penelitian dan Pengabdian Kepada Masyarakat, https://doi.org/10.24198/jppm.v2i2.13536

Gungor, R., \& Prins, E. (2010). Reproducing Gender Inequality: A Critical Discourse Analysis of a Turkish Adult Literacy Textbook. Adult Education Research Conference, Manhattan: Kansas State University Libraries New Prairie Press.

Kulju, P., Kupiainen, R., Wiseman, A. M., Jykiainen, A., Koskinen-Sinisalo, K.L., \& Makinen, M. (2018). A Review of Multiliteracies Pedagogy in Primary Classrooms. Language and Literacy, 20(2), 80-102.

Laksono, K., \& Retnaningdyah, P. (2018). Exploring The Use of Literacy Strategies in Junior High School Level. 173 (Icei 2017), https://doi.org/10.2991/icei-17.2018.44

Mills, K., A. (2006). Critical Framing in a Pedagogy of Multiliteracies. In Proceedings Australian Literacy Educator's Association/ Australian Association of the Teaching of English National Conference 2006: Voices, Vibes, Visions, Darwin,

Pahl, K., \& Rowsel, J. (2005). Literacy and Education. London: Paul Chapman Publishing.

Rogers, R. (2011). An Introduction to Critical Discourse Analysis in Education. In An Introduction to Critical Discourse Analysis in Education. New Jersey: Lawrence Erlbaum Associates https://doi.org/10.4324/9780203836149

Rogers, R., \& Mosley, M. (2008). A Critical Discourse Analysis of Racial Literacy in Teacher Education. Linguistics and Education ,19(2),107-131. https://doi.org/10.1016/j.linged.2008.02.002

United Nation. (2014). Gender Equality. Retrieved from http://www.un.org/sustainabledevelopment

Wallace, C. (2003). Critical Reading in Language Education. New York: Palgrave Macmillan https://doi.org/10.1057/9780230514447 